\title{
The Reliability of Critical Period Hypothesis
}

\author{
Zakaria Bziker (Corresponding author) \\ Ibn Tofail University, School of Humanities, Kenitra, Morocco \\ BP401, 14000, Kenitra, Morocco \\ Tel: 1-262-302-1239Ｅ-mail: zakaria.bziker@hotmail.com
}

Received: September 15, 2019 Accepted: October 14, 2019 Published: October 16, 2019

doi: 10.5296/ire.v8i1.15525

URL: https://doi.org/10.5296/ire.v8ii1.15525

\begin{abstract}
This article is an attempt to examine the reliability of the Critical Period Hypothesis (Note 1) in light of subsequent studies. The high improbability of successful L2 acquisition among adults is the main point of strength that $\mathrm{CPH}$ enjoys. However, we have incidents of nativelikeness with individuals that began L2 acquisition years past the critical period (Note 2) in addition to supporting studies that show ultimate attainment among L2 learners is still possible. In this case do we still talk about a reliable hypothesis? This opens us to ponder whether $\mathrm{CPH}$ is purely biological or there are other social construct factors at play that help some L2 adult learners to attain nativelikness despite the high unlikelihood of its occurrence.
\end{abstract}

Keywords: Critical period hypothesis, L2 learning, Ultimate attainment, Language fluency, $\mathrm{CPH}$, Language acquisition, Critical period

\section{Introduction}

The human brain is not a physiologically static organ. It is dynamic and changes with time as it has scientifically been proven (Kandel \& Tauc, 1965; Zucker \& Regehr, 2002). This change is called neuroplasticity and occurs at the level of neural pathways and neural cells. These changes are vital for the development of the brain as well as for it to function properly in terms of language processing and acquisition in early childhood development or cortical remapping in case of brain injury or damage. This dynamicity or flexibility of the brain is known in neurology as neuroplasticity. It was and still is believed that the plasticity of the brain is somehow locked or fixed after a period known as critical period, which is usually associated with the age of puberty. However, emerging evidence challenge this assumption. For instance we have Alarcón's pronunciation and ultimate attainment (Alarcón, 2011), the statistical critique of Vanhove (2013), and Lin's CP and phonological acquisition (Lin et al., 2016) in addition to other major critics of CPH like Krashen's Input Hypothesis (Krashen, 
1985). The Critical Period Hypothesis in cognitive psychology and language acquisition is the core of the on-going debate concerning the effect of brain plasticity on language acquisition. This debate is traced back to Penfield and Roberts (1959) earlier work that points out the relationship between difficulties of language acquisition and neural plasticity decline. The debate is not yet settled and some questions remain pending answers:

-To what extent is CP biological?

-Are there social factors that contribute to CP?

-Can CP be both biological and social?

-How reliable is the $\mathrm{CPH}$ ?

We will attempt to answer these questions and provide a scholarly critique of the hypothesis in question and then provide insights regarding other areas of research that needs attention.

\section{Challenges in the Critical Period Hypothesis}

The popularity of the $\mathrm{CPH}$ stems from the observable fact that the process of language acquisition (Note 3) that takes place after the CP is almost never identical to L1 acquisition (Norbert M. 2012, p. 1722). The statistical high improbability of attaining, a full mastery of a language after the $\mathrm{CP}$ seems to be the strongest evidence in favor of the hypothesis. However, the hypothesis does not completely exclude the possibility of successfull post-CP language acquisition. The case of Genie (Note 4), although it is striking evidence in favor of $\mathrm{CPH}$, it also demonstrates that post-CP language acquisition is still not all altogether impossible after-all. People do, to some extent, acquire L2 successfully after CP (Anne Fuchs 2007, p. 11, Curtiss 1977, p. 208; and Victoria A., 1974, p. 96). Acquiring L2 is still possible beyond CP, but the mastery of the language is repeatedly less successful. "One strong prediction made by some CPH exponents holds that post-CP learners cannot reach native-like L2 competences." (Vanhove, 2013). In addition to that, grammatical gender seems to be one of the main challenges for adult L2 learner (Hawkins, 2001; White et al., 2001; Sabourin, 2003; Blom et al., 2008). This high unlikelihood for adult L2 learners to attain a full mastery and fluency of L2 does not have to be deemed decisively unattainable. If a successful incident has happened at least once, then clearly we are missing a factor or a set of factors that are directly or indirectly responsible for the success of post-CP L2 acquisition. When these factors are not met, we tend to assume that L2 full mastery is unsuccessful due to biological constraints.

There is no agreement among researchers in regard to aspects of ultimate attainment and nativelikeness. Scovel and Long for example claim that one can be perfect at all levels of a language except pronunciation (Scovel 1988 paraphrased in Kees De 2005, p. 65). Researchers like Bongaerts claim that nativelikeness is still possible at all levels including pronunciation (Bongaerts, 1999 paraphrased in Herschensohn, 2000, p. 43), while Flege (1999) sees that it is rather the mother tongue's interference with L1 that influences the pronunciation but not the age (Flege, 1999 paraphrased in Herschensohn, 2000, p. 43). In addition to that, the age of $\mathrm{CP}$ is not determined, and has been assigned multiple ages like the ages of 12, 15, 16 or 18 years old (Muñoz, 2011, pp. 1-35). Some researches like Robert (1997) suggest that the critical period for language acquisition in the aspect of phonology starts as early as 12 months old (Robert, 1997, pp. 202-205). Views like Hyltenstam and Abrahamsson (2003) point to the 'non-consensus' regarding the relationship between age and 
$\mathrm{CP}$ effect on language acquisition and the biological interpretation drawn from this relation (2003, p. 563). All of these competing claims are now driving new researches to further investigate new venues of evidence in regards to CPH (Ortega, 2009, pp. 25-27).

\section{CPH Negative Results}

Despite of the decisive claim that $\mathrm{CPH}$ makes, it does not necessarily follow that one can never acquire a language after $\mathrm{CP}$ in the same way a developing child does. It is never too late to recreate the optimal circumstances for acquiring a language, except that there might be new factors at play once one steps beyond the CP phase. There are incidents of individuals that managed to reach the full mastery and fluency of L2 after the critical period. One example is the case of Julie, a British woman who moved to Egypt with her Egyptian husband at the age of 21. Georgette Ioup and her colleagues studied Julie's L2 ultimate attainment and found that she did exceptionally well (Ioup et al., 1994), and "passed herself off as a native speaker" (Ortega, 2015, p. 14).

The exceptional individuals who successfully acquire L2 similar to the case of Julie seem to defeat the decisiveness of the $\mathrm{CPH}$ although these are rare exceptions. A general rule is that exceptions never make the rules in the midst of the immense body of researches that support $\mathrm{CPH}$ claim. However, and by the same token, one might also argue that Genie's case, which supports the $\mathrm{CPH}$ argument, is after-all an exception. We do not have many cases of feral children to conduct an experiment and demonstrate that successful post-CP L1 acquisition is not possible as CPH claims. The available data is limited to a few cases. Maybe Genie was a victim to the same factors that affect L2 acquisition among adult learners and therefore it is still uncertain that biological traits have something to do with post-CP language acquisition process, or as Bialystok (1997) states:

The conclusion is that there is insufficient evidence to accept the claim that mastery of a second language is determined wholly, or even primarily by maturational factors (Bialystok, 1997, p. 116).

\section{How Reliable Is CPH?}

Reliability in the scientific method is one of the cornerstones of science. It ensures that a theory or a hypothesis is repeatable and holds itself consistent across time and space. In a nutshell, reliability ensures that the results of an experiment should be, to a great extent, predictable. As for the $\mathrm{CPH}$, results can sometimes be unpredictable. An instance of that is the case of Julie. The rationale behind reliability is to reinforce the theory or a hypothesis by means of confirming results from other experiments duplicated independently in different contexts and by different researchers. This is true for $\mathrm{CPH}$ but not entirelly consistent. If the results of an experiment are not matching the expected findings to a theory or a hypothesis, then this mismatch is a sign of an unaccounted for variable(s) or factor(s) that has affected the direction of the findings to a new territory. This does not necessarily mean that the hypothesis in question is false.

In many cases, researchers may find that the results of an experiment do not support the original hypothesis. When writing up these results, the researchers might suggest other options that should be explored in future studies. (Cherry, 2019)

These negative results are an invitation to expand the hypothesis to account for more 
variables until the mismatch or the anomalous becomes, as Kuhn puts it, "expected" (Kuhn, 1970, p. 52). If this is not attainable, then negative results could be a glimpse of a newly discovered phenomenon that needs attention and further exploration. The phenomenon could eventually evolve into its own hypothesis and maybe a full-fledge theory. In extreme cases, it could be an early stage of a paradigm shift if the hypothesis or theory is negating a grand theory. As for $\mathrm{CPH}$, there is a need for further exploring the outlier population and investigating the variables that contributed to the negative results. Instead of confirming and reconfirming the established assumption, we might find more answers and insights that would contribute to a deeper understanding of CP if outliers are studied.

\section{Potential Factors Responsible for Negative Results}

Researchers like Bongaerts (1999) recognize the hidden engine that drives the exceptional individuals to exceed in what the majority of ordinary people could not in post-CP language acquisition.

In sum, what we suggest is that the success of the exceptional adult learners we identified may have been at least partly due to the combination of three factors: high motivation, continued access to massive L2 input, and intensive training in the perception and production of L2 speech sounds. (Bongaerts, 1999, p. 155)

Motivation, exposure, and aptitudes are indispensible for post-CP adult learners in order to fully master their L2. In the same vein, Gardner (2001), and Cohen and Dörnyei (2001, p. 172) see that motivation is the prominent stimulus for successful L2 achievement. Maybe these conditions are rarely met for adults, which may explain their inability to achieve nativelikeness. However, children have no cognitive advantage over adults in acquiring pragmatics and sociolinguistic competences given that these competences are acquired in a lifelong process (Kasper, 1996, p. 158). One thing for sure is that the mechanisms involved in post-CP L2 acquisition seem to be qualitatively different from those involved in L1 acquisition. Thus it takes different methods of language acquisition to attain nativelikness for both children and adults.

If we assume, just for the sake of argument, that the efficiency of children's L1 acquisition is not biological, and that the inefficiency of adults' L2 acquisition is also not biological, what could then be the factors behind the difference in their language learning aptitude? Could it be that children happen to be eager to learn anything in their surrounding environment in the first few years of their life? Could it be that children are in a dire need for language in order to express their basic needs (wanting to eat, drink, or expressing distaste and negation for example) and to also interact with adults? It is a given fact that children have no say in their imposed mother tongue. They have no prior attitudes that affect their L1 acquisition. Their neutral attitudes toward the first language they acquire, and have to acquire, make them see it (L1) as just a survival tool with which to communicate. Adults on the other hand may not have that excessive thirst for knowledge children have and consequently less desire to acquire a second language. An example that supports this tentative claim is the minority of Spanish speakers and immigrants in the United States. Some of them can manage to live without the need of learning English: "You can get by quite nicely in the United States not speaking English in most parts of the country... for the Spanish-speaker in this country, there really is no critical need to learn English" (Gonzalez, 2007). Further, it is known that most immigrants 
in North America become bilingual immediately after arriving. However, some pockets of German immigrants and their descendants in Wisconsin persisted well until the $20^{\text {th }}$ century according to 1910 U.S. census and as far as 1930s according to Miranda's study of U.S. born monolingual German in Wisconsin (Miranda, 2008, p. 273). Seeing that adults are already in possession of L1 and know fairly well how to navigate the world even without language, it could be that they do not have that sharp need to express basic needs like children do. Thus the reasons that push an individual to learn L1 are fundamentally different from the reasons that push one to learn L2. It is also a matter of time allocation. Adults are part-time language learners whereas children are full-time. Maybe adults' attitudes and motivations towards L2 are not sufficient enough due to their other preoccupations in life. Maybe if adults had positive attitudes toward L2, in addition to enough exposure, they can miraculously master their L2 the same way children do. If that is the case, can we still ascribe changes in language aptitudes to biological factors? Could CPH be only targeting people with low aptitude that happen to consist the overwhelming majority?

\section{Conclusion}

Although Lenneberg (Note 5) strongly attribute CP to biology, it is nevertheless still unclear whether the qualitative difference between L2 and L1 acquisition is due to biological (innate) or environmental (construct) factors (Małgorzata, 2009). Complex behaviors such as language acquisition could be achieved by mingling both biological and external factors (Małgorzata, 2009, pp. 39-40). This nature-nurture on-going dilemma could be due to the fact that all factors behind the critical period are not yet pinned down. We may tend to think it is biological seeing that the critical period occurs at a specific time in the process of human development. In addition to that, ample evidence suggest that the brain undergoes a massive change during the puberty onset at the level of grey matter (Giedd et al., 2006; Peper et al., 2009b; Herting et al., 2015), at the level of white matter (Barnea-Goraly, 2005; Lebel et al., 2008), and at the level of synapses (Huttenlocher, 1979; Petanjek et al., 2011). These brain changes along with physiological changes that a human being undergoes during puberty coincide with abrupt change in the aptitude of language acquisition, and thus it follows that it is totally natural to assume that puberty and critical period are instances of the same thing and that this thing must be fundamentally biological. This is intuitive association, and has no ground in logic or science. The occurrence of two events at the same time is not causal, but rather correlative.

We have no other notion of cause and effect, but that of certain objects, which have been always conjoined together, and which in all past instances have been found inseparable. We cannot penetrate into the reason of the conjunction. We only observe the thing itself, and always find that from the constant conjunction the objects acquire an union in the imagination. When the impression of one becomes present to us, we immediately form an idea of its usual attendant; and consequently we may establish this as one part of the definition of an opinion or belief, that it is an idea related to or associated with a present impression. Hume (1739).

\section{References}

Alarcón, I. (2011). Critical period hypothesis revisited: The impact of age on ultimate 
attainment in the pronunciation of a foreign language edited by Jedynak, Malgorzata. The Modern Language Journal, 95(1), 144-146. https://doi.org/10.1111/j.1540-4781.2011. 01152.x

Barnea-Goraly, N. (2005). White Matter Development During Childhood and Adolescence: A Cross-sectional Diffusion Tensor Imaging Study. Cerebral Cortex, 15(12), 1848-1854. https://doi.org/10.1093/cercor/bhi062

Bialystok, E. (1997). The structure of age: in search of barriers to second language acquisition. Second Language Research. https://doi.org/10.1191/026765897677670241

Blom, E., Polišenská, D., \& Weerman, F. (2008). Articles, adjectives and age of onset: The acquisition of Dutch grammatical gender. Second Lang. Res, 24, 297-331. https://doi.org/10.1177/0267658308090183

Bongaerts, T. (1999). Ultimate attainment in L2 pronunciation: The case of very advanced late L2 learners. In D. Birdsong (Ed.), Second language acquisition and the critical period hypothesis (pp. 133-159). Mahwah, NJ: Lawrence Erlbaum Associates.

Bongaerts, T. (2005). Introduction: Ultimate attainment and the critical period hypothesis for second language acquisition. International Review of Applied Linguistics, 43, 259-267. https://doi.org/10.1515/iral.2005.43.4.259

Castillo M. (2013). The scientific method: a need for something better? AJNR Am J Neuroradiol, 34(9), 1669-71. https://doi.org/10.3174/ajnr.A3401

Cherry, K. (2019). How to Form a Hypothesis Statement for Psychology Research. Verywell Mind, $\quad$ Retrieved $\quad$ Oct. $\quad 10^{\text {th }} \quad 2019$, from https://www.verywellmind.com/what-is-a-hypothesis-2795239\#citation-1

Cohen, A. D., \& Dörnyei, Z. (2001). Taking my motivational temperature on a language task. Minneapolis, MN: Center for Advanced Research on Language Acquisition, University of Minnesota. $\quad$ Retrieved $\quad$ October $\quad 10^{\text {th }} \quad 2019$, from https://sites.google.com/a/umn.edu/andrewdcohen/docments/2001-Cohen\%26DornyeiTaking My MotivationalTemperature.pdf

Curtiss, S. (1977). Genie: a psycholinguistic study of a modern-day "wild child". New York: Academic Press, Print. https://doi.org/10.1016/B978-0-12-196350-7.50009-3

Fromkin, V. A., \& Robert, D. R. (1974). An introduction to language. New York: Holt, Rinehart and Winston, Print.

Fuchs, A. (2007). The Critical Period Hypothesis supported by Genie's case. München: GRIN Verlag, Print.

Gardner, R. C. (2001). Integrative motivation and second language acquisition. In Z. Dörnyei, \& R. Schmidt (Eds.), Motivation and second language acquisition (pp. 1-9). Honolulu, HI: The University of Hawaii, Second Language Teaching \& Curriculum Center.

Giedd, J. N., Clasen, L. S., Lenroot, R., Greenstein, D., Wallace, G. L., Ordaz, S., ..., Chrousos, 
G. P. (2006). Puberty-related influences on brain development. Molecular and Cellular Endocrinology, 254-255, 154-162. https://doi.org/10.1016/j.mce.2006.04.016

Gonzalez, R. (2011, October 11). Success With Hispanics: Why Don't Hispanics Learn English? $\quad$ Retrieved $\quad$ October $\quad 9, \quad 2019$, from https://www.roofingcontractor.com/articles/85682-success-with-hispanics-why-don-t-hispani cs-learn-english

Hawkins R. (2001). The theoretical significance of Universal Grammar in second language acquisition. Second Lang. Res, 17, 345-367. https://doi.org/10.1177/026765830101700404

Herting, M. M., Gautam, P., Spielberg, J. M., Dahl, R. E., \& Sowell, E. R. (2015). A Longitudinal Study: Changes in Cortical Thickness and Surface Area during Pubertal Maturation. Plos One, 10(3). https://doi.org/10.1371/journal.pone.0119774

Hume, D., David, F. N., \& Mary, J. N. (2000). A Treatise of Human Nature. Oxford: Oxford University Press, Print.

Huttenlocher, P. R. (1979). Synaptic density in human frontal cortex - Developmental changes and effects of aging. Brain Research, 163(2), 195-205. https://doi.org/10.1016/0006-8993(79)90349-4

Hyltenstam, K., \& Abrahamsson, N. (2003). Maturational constraints in SLA. In C. J., Doughty, \& M. H. Long (Eds.), The handbook of second language acquisition (pp. 539-588). Malden, MA: Blackwell Publishers.

Ioup, G. (1994). Reexamining the Critical Period Hypothesis: A Case Study of Successful Adult SLA in a Naturalistic Environment. Studies in Second Language Acquisition, 16(1), 73-98. https://doi.org/10.1017/S0272263100012596

Jedynak, M. (2009). Critical period hypothesis revisited: the impact of age on ultimate attainment in the pronunciation of a foreign language. Frankfurt am Main: Peter Lang, Print.

Kandel, E. R., \& Tauc, L. (1965). Mechanism of heterosynaptic facilitation in the giant cell of the abdominal ganglion of Aplysia depilans. J. Physiol., 181, 28-47. https://doi.org/10.1113/jphysiol.1965.sp007743

Kasper, G., \& Schmidt, R. (1996). Developmental Issues in Interlanguage Pragmatics. Studies in Second Language Acquisition, 18(2), 149-169. https://doi.org/10.1017/S0272263100014868

Krashen, S. (1977). Some issues relating to the Monitor Model. In H. D. Brown, C. Yorio, \& R. Crymes (Eds.) Teaching and Learning English as a Second Language: Trends in Research and Practice (pp. 144-158). Washington, DC: TESOL.

Krashen, S. D. (1985). The input hypothesis: Issues and implications. London \& New York: Longman.

Kuhn, T. (1970). The structure of scientific revolutions (2nd ed.). Chicago: University of Chicago Press. 
Lallana, G. R. (2017, January). Critical Period Hypothesis: An Overview of Early Major Studies Second Language Acquisition (Unpublished master's thesis). Institute of Education, University of London Retrieved October 9, 2019, from https://www.academia.edu/32056601/Critical_Period_Hypothesis_An_Overview_of_Early_ Major_Studies_Second_Language_Acquisition

Lebel, C., Walker, L., Leemans, A., Phillips, L., \& Beaulieu, C. (2008). Microstructural maturation of the human brain from childhood to adulthood. NeuroImage, 40(3), 1044-1055. https://doi.org/10.1016/j.neuroimage.2007.12.053

Lenneberg, E. H. (1967). Biological foundations of language. New York: Wiley. https://doi.org/10.1080/21548331.1967.11707799

Lin, H.-Y., Hung, M., \& Wang, H.-J. (2016). The Critical Period Hypothesis Revisited: An Investigation of Taiwanese University EFL Learners' Production of Two English Consonants. Arab World English Journal (AWEJ), 7(2). https://doi.org/10.24093/awej/vol7no2.28

Miranda, E. W., \& Joseph, S. (2008). “GOOD Old Immigrants of Yesteryear,” Who Didn't Learn English: Germans in Wisconsin. American Speech, 83(3), 259-283. https://doi.org/10.1215/00031283-2008-020

Muñoz, C., \& Singleton, D. (2011). A critical review of age-related research on L2 ultimate attainment. Language Teaching, 44, 1-35. https://doi.org/10.1017/S0261444810000327

Ortega, L. (2009). Age. In B. Comrie, \& G. Corbett (Eds.), Understanding Second Language Acquisition. Abingdon: Routledge.

Ortega, L. (2015). Understanding Second Language Acquisition. Routledge. https://doi.org/ $10.4324 / 9780203777282$

Penfield, W., \& Roberts, L. (1959). Speech and brain mechanisms. Princeton: Princeton University Press.

Penfield, W., \& Roberts, L. (1959). Speech and brain mechanisms. Princeton, NJ, US: Princeton University Press.

Peper, J. S., Schnack, H. G., Brouwer, R. M., Baal, G. C. M. V., Pjetri, E., Székely, E., ... Hulshoff Pol, H. E. (2009). Heritability of regional and global brain structure at the onset of puberty: A magnetic resonance imaging study in 9-year-old twin pairs. Human Brain Mapping, 30(7), 2184-2196. https://doi.org/10.1002/hbm.20660

Petanjek, Z., Judaš, M., Šimić, G., Rašin, M. R., Uylings, H. B. M., Rakic, P., \& Kostović, I. (2011). Extraordinary neoteny of synaptic spines in the human prefrontal cortex. Proceedings of the National Academy of Sciences, 108(32), 13281-13286. https://doi.org/10.1073/ pnas. 1105108108

Piekarski, D. J., Johnson, C. M., Boivin, J. R., Thomas, A. W., Lin, W. C., Delevich, K., ... Wilbrecht, L. (2017). Does puberty mark a transition in sensitive periods for plasticity in the associative neocortex?. Brain Research, 1654(PtB), 123-144. https://doi.org/10.1016/ 
j.brainres.2016.08.042

Robert, J. R. (1997). A Time Frame of Critical/Sensitive Periods of Language Development. Acta Oto-Laryngologica, 117(2), 202-205. https://doi.org/10.3109/00016489709117769

Sabourin L. (2003). Grammatical Gender and Second Language Processïng: An ERP Study. Ph.D. dissertation, Groningen, Grodil.

Scovel, T. (2000). A critical review of the critical period research. Annual Review of Applied Linguistics, 20, 213-223. https://doi.org/10.1017/S0267190500200135

Seel, N. M. (2012). Encyclopedia of the sciences of learning. S.1.: Springer, Print. https://doi.org/10.1007/978-1-4419-1428-6

Taub, M. B. (2012). Visual diagnosis and care of the patient with special needs. Philadelphia: Wolters Kluwer Health/Lippincott Williams \& Wilkins, Print.

Vanhove, J. (2013). The critical period hypothesis in second language acquisition: A statistical critique and a reanalysis. PloS one, 8(7) e69172. https://doi.org/10.1371/journal. pone. 0102922

White, L., Valenzuela, E., Kozlowska-MacGregor, M., Leung, I. Y.-K., \& Ben Ayed, H. (2001). "The status of abstract features in interlanguage: Gender and number in L2 Spanish," In BUCLD 25: Proceedings of the 25th annual Boston University Conference on Language Development. pp. 792-802, Somerville, MA: Cascadilla. Press.

Zucker, R. S., \& Regehr, W. G. (2002). Short-term synaptic plasticity. Annu. Rev. Physiol., 64, 355-405. https://doi.org/10.1146/annurev.physiol.64.092501.114547

\section{Glossary}

CPH: Critical Period Hypothesis

CP: Critical Period

L2: $2^{\text {nd }}$ Language

L1: $1^{\text {st }}$ Language

\section{Notes}

Note 1. Critical Period Hypothesis: "Is the notion that language is best learned during the early years of childhood and that after about the first dozen years of life, everyone faces certain constraints in the ability to pick up a new language" (Scovel, 1988, p. 2)

Note 2. Critical period: “... a time during post natal life when the development and maturation of functional properties of the brain, its 'plasticity', is strongly dependent on experience or environmental experience"- Sengpiel (Quoted in Marc B. Taub, 2012, p. 275). First 
introduced by Penfield and Roberts in 1959 and then expanded by Lenneberg in subsequent years.

Note 3. The 'acquisition' term in this article is used in its Krashenian sense in his acquisitionlearning hypothesis. This is a subconscious process of acquiring a language in an immersive environment similar to contexts where native languages are developed. Krashen (1977).

Note 4. Genie: a feral child that spent her first thirteen years without any language input.

Note 5. Eric Heinz Lenneberg (1921/1975) is a Jewish German linguists and neurologist. He is known by his biological approach to language and language acquisition. In his Biological Foundations of Language (1967) he advanced his critical period hypothesis which is still a debatable issue in linguistics and cognitive psychology.

\section{Copyright Disclaimer}

Copyright reserved by the authors.

This article is an open-access article distributed under the terms and conditions of the Creative Commons Attribution license (http://creativecommons.org/licenses/by/3.0/). 